\title{
Genevieve Edmonds and Luke Beardon (Eds): Asperger Syndrome \& Employment: Adults Speak Out about Asperger Syndrome
}

\author{
London, UK, Jessica Kingsley Publishers, 2008, 176 pp., \$19.95 (paper)
}

\author{
Ernst O. VanBergeijk
}

Published online: 3 June 2009

(C) Springer Science+Business Media, LLC 2009

With an unemployment rate approaching 90\% among the Autism Spectrum (AS) population, a book of this nature is long over due. Edmonds and Beardon call for a migration from the pathological nature of the medical model of autism with its emphasis upon the "Triad of Impairments"first described by Wing and Gould (1979), to a strengths based model. Through the personal employment journeys of fifteen adults and two parents of individuals with Asperger Syndrome, the editors attempt to focus upon a strengths model of individuals with AS. This book is ideal for adults with Asperger Syndrome, their parents, and potential employers. It is meant to provide understanding, concrete suggestions, and hope to individuals with AS and their employers who are struggling with issues surrounding employment.

A number of impressions will strike the reader. The contributors to this edition are astute observers of their condition and the foibles of the neurotypical world. Their articulate descriptions of their struggles in the world of work give us a glimpse of their thought processes and their sheer determination to maintain employment in the face of a series of obstacles. In reading some of the chapters, the writer's anxiety is almost palpable which give the reader a renewed sense of empathy for the Aspergeic population. Each person's story is heartfelt and earnest. Some are brutally frank and others are quite wry and funny. The most striking impression is the fact that despite many set backs, the authors continue in their quest to find employment that

E. O. VanBergeijk $(\bowtie)$

Vocational Independence Program, New York Institute of Technology, 300 Carleton Avenue, Room 112 Independence Hall, Central Islip, NY 11722, USA

e-mail: evanberg@nyit.edu matches their skills. Many of us would have given up long ago.

For individuals with Asperger Syndrome, the job interview is a major obstacle. The contributors give specific advice regarding how to prepare for, and behave during a job interview. They discuss the transition from school or training programs to the beginning weeks of a new job. Among their suggestions include previewing the route to the job and other travel tips, relaxation techniques, clothing advice, lunch tips, organizational techniques, and how to handle invitations to social gatherings after work. This advice is invaluable to the individuals with AS and their families.

Employers will benefit from similar suggestions. Each employee with Asperger Syndrome is unique. It is incumbent upon the employer to determine with the employee the best way to communicate with each other, ways to improve clarity in their two way communications, setting up clear expectations and deadlines surrounding a task, and matching the employee's strengths with the work that needs to be completed. Many of the contributors reference employment laws and programs that are UK based. American and Canadian readers will need to refer to comparable laws in their home countries.

As Shepherd writes in Chap. 4, "Employing an Aspergic presents a whole new set of challenges but the benefits can be tremendous. You want employee loyalty? You got it. You want precision, honesty, punctuality, dedication? You got it" (p. 57). The positive qualities he describes of Aspergic employees are qualities that can positively impact a corporation's profits. The high unemployment rates among the AS population harms not only the individuals involved, but society as a whole. This book provides a practical guide and personal testimonies to help address this pressing issue. 